\title{
A STUDY OF HOUSES WITH DALANS IN ASHEQAN WA AREFAN, KABUL CITY, AFGHANISTAN
}

\author{
アフガニスタン、カブール市アシュカン・ワ・アレファン地区のダーラーン付き住宅の研究
}

\author{
Mohammad Umar AZIZI and Tetsuya ANDO \\ モハンマドウマール アジジ*1, 安 藤徹 哉*2
}

This paper aims to study the characteristics of houses with covered walkway structures known locally as Dalan in the Asheqan wa Arefan quarter of Kabul Old City, Afghanistan. It examines their locations, distribution, access, number of stories, plan types, space usages, and reasons for the construction and destruction of traditional Dalans. The house locations and their accessibility networks are drawn based on a satellite image followed by detailed field surveys conducted between 2018 and 2019. Conclusions are drawn for the conservation of Dalans as part of the cultural heritage in the historical landscape.

Keywords: Dalan, covered walkway, traditional houses, conservation, Kabul Old City, Afghanistan ダーラーン, 覆い付き通路, 伝統住宅, 保全, カブール旧市街地, アフガニスタン

\section{Introduction}

Kabul, the capital of Afghanistan, was once an oasis town along the ancient trade routes between Persia and China, India, and beyond. In the present Kabul, District 1 is the oldest residential area (Fig. 1). However, many historical quarters in District 1 were damaged between 1992 and 1996 due to civil wars.1) Among the quarters, the Asheqan wa Arefan quarter is the least damaged (Fig. 2).2),3),4) In this quarter, traditional houses still display the way of living of old Kabulis. ${ }^{5)}$ Some traditional houses have structures called "Dalan" constructed over the path (Fig. 8).

There are several terms used for the covered walkway structures in the world. A common term used in European countries is Arcade, referring to the glass-covered passageways that connect two major streets consisting of shops and houses. ${ }^{6}$ Meanwhile, Suq and Sabat are common terms used across Arabic-Islamic, Turkic, and Iranian countries (Fig. 3). Suq often refers to old covered bazaars, and Sabat refers to the covered structures of residential houses. ${ }^{7)}$ In Afghanistan, the local term Dalan is used for walkways covered with a structure built as part of a

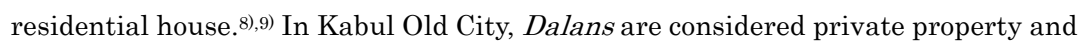
are owned by the owners of the respective houses.

There are no previous studies specifically focusing on houses with Dalans in Kabul. The study on the transformation of residential settlements in Kabul by Nabizada et al. (2012) ${ }^{10}$ ) covers the Asheqan wa Arefan quarter, but only one Dalan is shown on the map as a covered street. Azizi et al. (2020)5) studied traditional houses in the western part of Asheqan wa Arefan quarter and identified several types of house plans with courtyards but did not discuss Dalans. Outside of Kabul, Kawish et al. (2019)9) studied traditional houses with domical vault roofs and Dalans in Bagh-e Dasht, Herat city.

Thus, this paper aims to clarify the characteristics of Dalans in the Asheqan wa

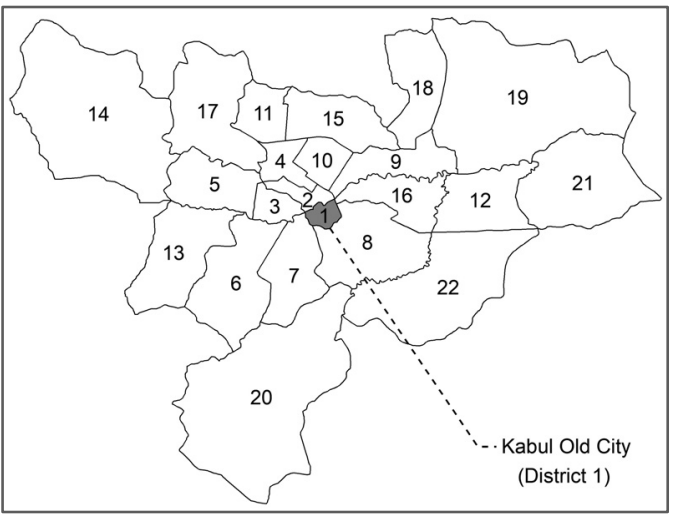

Fig. 1 Kabul and its 22 districts

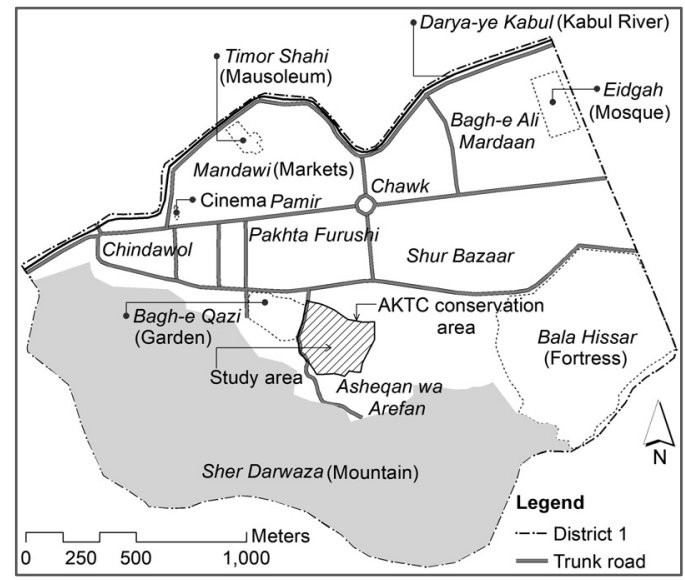

Fig. 2 Site map of the study area
"1 Postdoctoral Fellow, Grad. School of Engineering and Science, University of the Ryukyus, Dr.Eng.

Prof., Faculty of Engineering, University of the Ryukyus, Dr.Eng.
琉球大学大学院理工学研究科博士研究員 博士 (工学)

琉球大学工学部 教授・博士 (工学) 
Arefan quarter of Kabul Old City (Fig. 2). It examines their locations, distribution, access, the number of stories, plan types, space usages, and analysis of reasons for their construction and destruction. The house locations and their accessibility networks were drawn based on a satellite image from 2018 (Fig. 4). Field surveys were then conducted in February 2018 (western part) and July 2019 (eastern part). i)

\section{Physical Characteristics of Houses with Dalans}

\subsection{Distribution of Dalans}

Based on satellite images and field surveys, the locations and types of 249 houses in the Asheqan wa Arefan quarter have been indicated on the map (Fig. 4). Three types of houses are found: 1 ) traditional (146 or 58.6\%), 2) modern (55 or $22.1 \%$ ), and 3) mixed (48 or 19.3\%).ii) 35 of the 249 houses have Dalans. The residents of three Dalan houses were unavailable or declined to respond to surveys; therefore, 32 Dalans were studied in total (Fig. 5).iii) In addition, through the questionnaires, it was possible to identify the locations of 11 destroyed Dalans.

Streets are classified into main streets, sub-streets, and streets with dead-ends (Table 1). Main streets are accessible by cars and to pedestrians. Sub-streets are accessible only to pedestrians. Streets with dead-ends have one entrance/exit, accessible only to pedestrians. The number of Dalans on streets with dead-ends is higher (20 or $62.5 \%$ ) compared to those on sub-streets (12 or 37.5\%). There are no Dalan on the main streets, and the degree of concentration (number of units per distance) is higher on streets with deadends. This indicates that Dalans tend to be located in fairly private areas with low traffic.

There are two types of Dalansidentified based on construction materials (Table 1): traditional (27 or $84.4 \%$ ) and modern (5 or $15.6 \%$ ). Traditional Dalans are made of local construction materials such as stone masonry, sun-dried bricks, wooden poles, and mud. Modern Dalans are built with industrialized construction materials such as fired bricks, steel, concrete, and cement. The fact that Dalans are still being built shows that they have not been reduced to historical relics. The distribution of traditional Dalans and modern Dalans differs. The traditional Dalans are found more on streets with dead-ends (18 or 66.7\%) than on sub-streets (9 or $33.3 \%$ ). On the other hand, among the five modern Dalans, three are found on sub-streets $(60.0 \%)$ and two on streets with dead-ends $(40.0 \%)$. The degree of concentration (number of units per distance) of traditional Dalans is higher on streets with dead-ends. The degree of concentration of modern Dalans is higher on sub-streets. According to the current municipality law (enforcement year: 2000, issue no. 794), building on land not authorized by the municipality is not permitted. Therefore, building over-structures above public property such as streets is illegal Despite the regulation, modern Dalans are still being built after 2000.

There are three combinations of house types with Dalan (Table 2). Among them, traditional houses with traditional Dalan are the most common (23 or $71.9 \%$ ). In the case of mixed houses, four out of five have traditional Dalans while one has a modern Dalan. It is assumed that the mixed houses with the traditional Dalan have kept their old Dalan during the renovation of the houses, while the house with the modern Dalan has had its Dalan newly rebuilt during the renovation. Modern houses only have modern Dalan.

\subsection{Dimensions and usages of Dalans}

In this study, a one-story Dalan refers to a roof covered walkway without any rooms above it. There are no one-story Dalan located in the study area. A two-story Dalan refers to a structure in which the first floor is a walkway and the second floor forms part of a house. ${ }^{\text {iv) }}$ A three-story Dalan refers to a structure in which the first floor is a walkway and the second and third floors form part of a house. Among the traditional Dalans (Table 3), the majority (21 or 77.8\%) are two-storied, and the others (6 or 22.2\%) are three-storied. All of the modern Dalans are three-storied (5 or 100.0\%). The new three-story Dalans built with industrialized construction materials are changing traditional landscape with two-story Dalans constructed with traditional materials.
Table 3 Dalan types and no. of stories

\begin{tabular}{|c|c|c|c|c|c|c|c|c|}
\hline Dalan types & One-story & \multicolumn{2}{|c|}{ Two-story } & Three-story & \multicolumn{2}{|c|}{ Total } \\
\hline Traditional & 0 & $0.0 \%$ & 21 & $77.8 \%$ & 6 & $22.2 \%$ & 27 & $100.0 \%$ \\
\hline Modern & 0 & $0.0 \%$ & 0 & $0.0 \%$ & 5 & $100.0 \%$ & 5 & $100.0 \%$ \\
\hline Total & 0 & $0.0 \%$ & 21 & $65.6 \%$ & 11 & $34.4 \%$ & 32 & $100.0 \%$ \\
\hline
\end{tabular}


The number of stories of Dalan and houses is analyzed in Table 4. Of the 21 traditional two-storied Dalans, 12 (57.1\%) form parts of houses with two-stories, while nine (42.9\%) form parts of houses with three stories. Of the six traditional three-storied Dalans, one (16.7\%) forms parts of the house with two-stories and five (83.3\%) form parts of houses with three-stories. Therefore, most traditional Dalans match the number of stories with their houses. All five modern Dalans have three-stories; four (80.0\%) form parts of houses with three-stories, and one $(20.0 \%)$ form parts of houses with four-stories. Therefore, most modern Dalans also match the number of stories of their houses. When the number of floors does not match between a Dalan and a house, the lower roof is used as a safe outdoor space.

Table 4 No. of stories of Dalans and houses

\begin{tabular}{|c|c|c|c|c|c|c|c|c|c|c|c|}
\hline \multirow[b]{2}{*}{ Dalan types } & \multirow{2}{*}{$\begin{array}{l}\text { No. of } \\
\text { Dalan } \\
\text { stories }\end{array}$} & \multicolumn{8}{|c|}{ No. of house stories } & \multirow{2}{*}{\multicolumn{2}{|c|}{ Total }} \\
\hline & & & 1 & & 2 & & 3 & & 4 & & \\
\hline \multirow{2}{*}{ Traditional } & 2 & 0 & $0.0 \%$ & 12 & $57.1 \%$ & 9 & $42.9 \%$ & 0 & $0.0 \%$ & 21 & $100.0 \%$ \\
\hline & 3 & 0 & $0.0 \%$ & 1 & $16.7 \%$ & 5 & $83.3 \%$ & 0 & $0.0 \%$ & 6 & $100.0 \%$ \\
\hline \multirow{2}{*}{ Modern } & 2 & 0 & $0.0 \%$ & 0 & $0.0 \%$ & 0 & $0.0 \%$ & 0 & $0.0 \%$ & 0 & $0.0 \%$ \\
\hline & 3 & 0 & $0.0 \%$ & 0 & $0.0 \%$ & 4 & $80.0 \%$ & 1 & $20.0 \%$ & 5 & $100.0 \%$ \\
\hline \multicolumn{2}{|c|}{ Total } & 0 & $0.0 \%$ & 13 & $40.6 \%$ & 18 & $56.3 \%$ & 1 & $3.1 \%$ & 32 & $100.0 \%$ \\
\hline
\end{tabular}

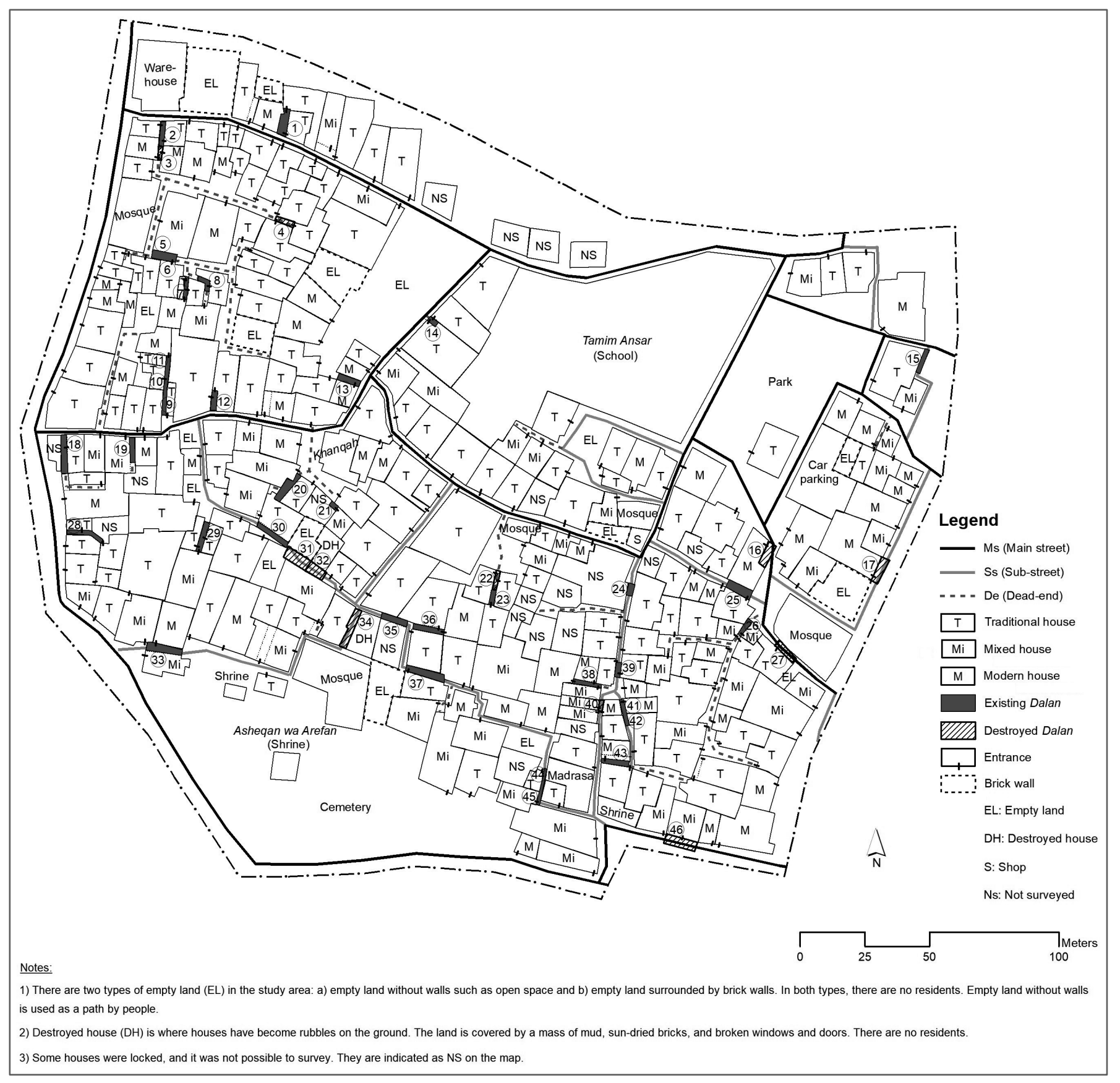

Fig. 4 Site map of Dalans in the study area 


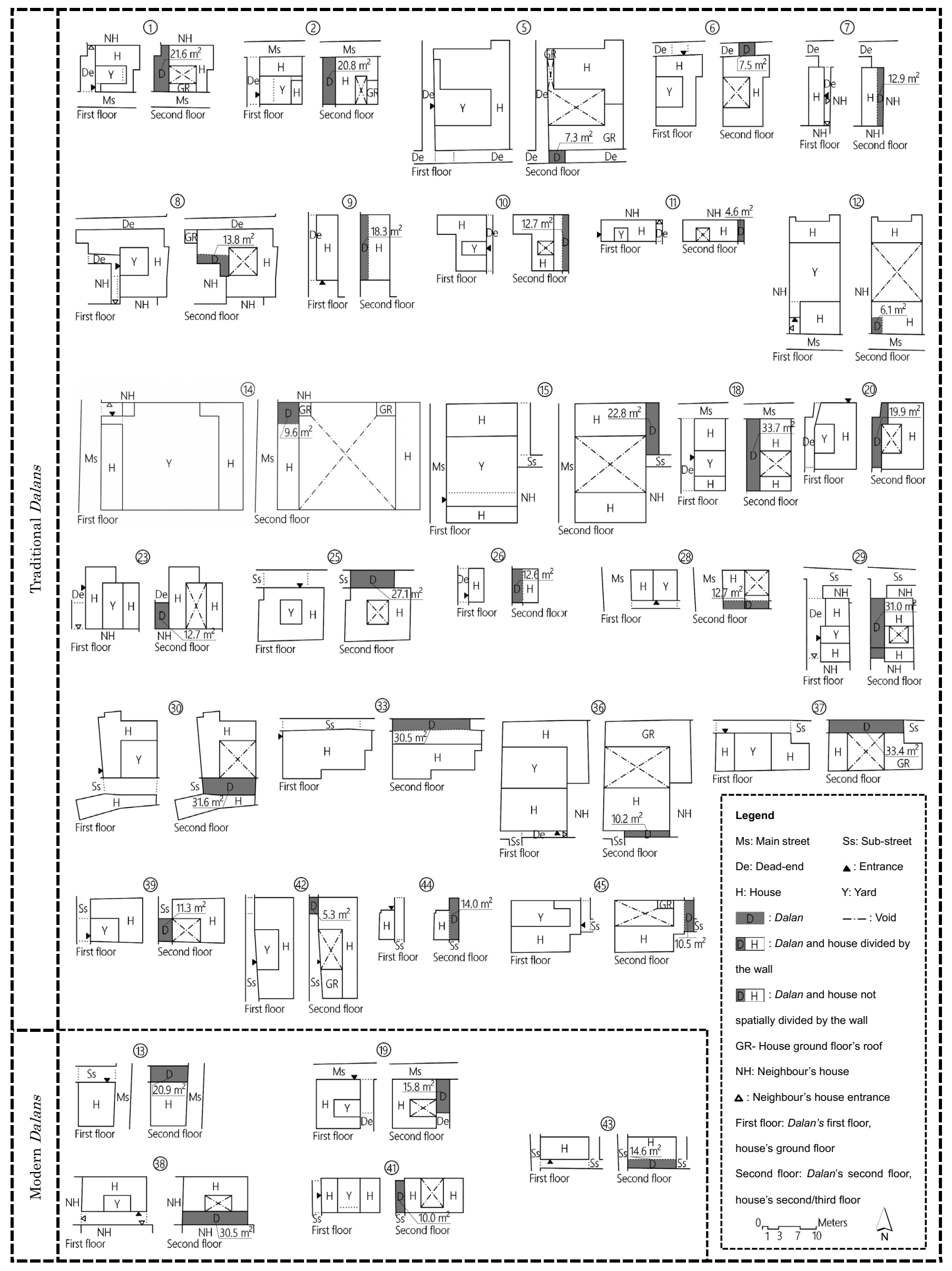

Fig. 5 Plan of 32 Dalans with houses 
Three types of supports have been identified for Dalans (Table 5): 1) pillars only, 2) wall only, and 3) combined use of pillars and wall. On the house side, all Dalans, both traditional and modern, have no pillar except two Dalans that have both walls and pillars for reinforcement. However, on the opposite side of houses, half of traditional Dalans (13 or 48.1\%) are supported by pillars, while all modern Dalans are supported by walls rather than pillars. Independent pillars are found only on the opposite side. There are several possibilities that might explain the reasoning behind using independent pillars on the opposite side. Firstly, house owners may want to create structural support for their Dalan by attaching beams to the walls of the house on the opposite side, in which case pillars are unnecessary. However, the residents on the opposite side may oppose modifications to their wall. Furthermore, even if the neighbours were to agree, the wall on the opposite side may not be structurally sound enough to act as a support. Thus, house owners may choose to use independent pillars on the opposite side.

The relationship between the number of stories and supports of Dalans is examined in Table 6. Among two-story Dalans, the ratio of pillar support on opposite side is more (9 or $42.9 \%$ ) than that of three-story Dalans (4 or $36.4 \%$ ). This suggests that the number of stories of Dalan, in other words, the structural load, is not the only factor related to the need for pillars. Taking this into consideration, other reasons for using pillars to support Dalan maybe lack of consensus with neighbours or the lack of structural integration of Dalan and the house wall.

Based on the field surveys, out of 32 Dalans, 20 or $62.5 \%$ are divided by the wall (150-400mm in thickness) with a door from the house, while 12 or $37.5 \%$ are not spatially divided (as shown in Fig. 5). Approximately two-thirds of Dalans are independent of the house functionally. Table 7 shows the number of rooms in Dalans. 17 or $53.1 \%$ of Dalans have two rooms, and 13 or $40.6 \%$ have one room. The two-room Dalans tend to have a larger area than the one-room Dalans. Table 8 shows the usage of Dalans. Regardless of Dalan's area, the most common use is the living room (23 or $71.9 \%$ ). Other uses include storage, bathrooms, and a hall.v)

\subsection{Consideration of reasons for building Dalans}

Most of the current residents of houses with traditional Dalans are not residents at the time of construction; therefore, they do not know the original purpose of the Dalans. There are several possible reasons for building Dalans.

The first is to provide protection against climate, much like an arcade or front porch. Unlike arcades, Dalans in the study area are not continuous. Therefore, the positional relationship between the entrance and Dalans is examined in Table 9. ${ }^{\text {vi) }}$ There are 21 or 65.6\% Dalans with an entrance underneath and 11 or $34.4 \%$ Dalans without an entrance underneath. 17 or $63.0 \%$ of traditional Dalans and houses have their entrance underneath Dalan. This indicates that protection against the climate is one of the major factors to build Dalans. The proportion of Dalans with entrances underneath is higher among modern Dalans (4 or $80.0 \%$ ) than among traditional ones (17 or 63.0\%). This shows that modern Dalans follow the tendency that traditional Dalans show. The positional relationship between the entrances and Dalans is examined by locations in Table 10. The percentage of Dalans with an entrance underneath is higher on streets with dead-ends (14 or 66.7\%) than those on sub-streets ( 7 or $33.3 \%$ ). This indicates that entrances along streets with dead-ends are more protected against climate.

The second possible reason is to provide extra space for houses. The study area is densely built up, and there is limited space to add
Table 5 Types and supports of Dalans

\begin{tabular}{|c|c|c|c|c|c|c|c|c|}
\hline \multirow{2}{*}{ Dalan types } & \multicolumn{6}{|c|}{ House side } & \multirow{2}{*}{\multicolumn{2}{|c|}{ Total }} \\
\hline & \multicolumn{2}{|c|}{ Pillar } & \multicolumn{2}{|c|}{ Wall } & \multicolumn{2}{|c|}{ Pillar+Wall } & & \\
\hline Traditional & 0 & $0.0 \%$ & 25 & $92.6 \%$ & 2 & $7.4 \%$ & 27 & $100.0 \%$ \\
\hline Modern & 0 & $0.0 \%$ & 5 & $100.0 \%$ & 0 & $0.0 \%$ & 5 & $100.0 \%$ \\
\hline Total & 0 & $0.0 \%$ & 30 & $93.8 \%$ & 2 & $6.2 \%$ & 32 & $100.0 \%$ \\
\hline \multirow{2}{*}{ Dalan types } & \multicolumn{6}{|c|}{ Opposite side } & \multirow{2}{*}{\multicolumn{2}{|c|}{ Total }} \\
\hline & \multicolumn{2}{|c|}{ Pillar } & \multicolumn{2}{|c|}{ Wall } & \multicolumn{2}{|c|}{ Pillar+Wall } & & \\
\hline Traditional & 13 & $48.1 \%$ & 14 & $51.9 \%$ & 0 & $0.0 \%$ & 27 & $100.0 \%$ \\
\hline Modern & 0 & $0.0 \%$ & 5 & $100.0 \%$ & 0 & $0.0 \%$ & 5 & $100.0 \%$ \\
\hline Total & 13 & $40.6 \%$ & 19 & $59.4 \%$ & 0 & $0.0 \%$ & 32 & $100.0 \%$ \\
\hline
\end{tabular}

Table 6 No. of stories and supports of Dalans

\begin{tabular}{|c|c|c|c|c|c|c|c|c|}
\hline \multirow{2}{*}{$\begin{array}{c}\text { No. of Dalan } \\
\text { stories }\end{array}$} & \multicolumn{6}{|c|}{ House side } & \multirow{2}{*}{ Total } \\
\cline { 2 - 7 } & Pillar & \multicolumn{3}{|c|}{ Wall } & Pillar+Wall & \multicolumn{1}{c|}{} \\
\hline Two-story & 0 & $0.0 \%$ & 19 & $90.5 \%$ & 2 & $9.5 \%$ & 21 & $100.0 \%$ \\
\hline Three-story & 0 & $0.0 \%$ & 11 & $100.0 \%$ & 0 & $0.0 \%$ & 11 & $100.0 \%$ \\
\hline Total & 0 & $0.0 \%$ & 30 & $93.8 \%$ & 2 & $6.2 \%$ & 32 & $100.0 \%$ \\
\hline $\begin{array}{c}\text { No. of Dalan } \\
\text { stories }\end{array}$ & \multicolumn{6}{|c|}{ Pillar } & \multicolumn{3}{|c|}{ Wall } & Pillar+Wall & \multirow{2}{*}{ Total } \\
\hline Two-story & 9 & $42.9 \%$ & 12 & $57.1 \%$ & 0 & $0.0 \%$ & 21 & $100.0 \%$ \\
\hline Three-story & 4 & $36.4 \%$ & 7 & $63.6 \%$ & 0 & $0.0 \%$ & 11 & $100.0 \%$ \\
\hline Total & 13 & $40.6 \%$ & 19 & $59.4 \%$ & 0 & $0.0 \%$ & 32 & $100.0 \%$ \\
\hline
\end{tabular}

Table 7 Floor areas and no. of rooms of Dalans

\begin{tabular}{|c|c|c|c|c|c|c|c|c|c|c|}
\hline $\begin{array}{c}\text { Dalan areas } \\
\left(\mathrm{m}^{2}\right)\end{array}$ & \multicolumn{2}{|c|}{1 room } & \multicolumn{2}{|c|}{2 rooms } & \multicolumn{2}{c|}{3 rooms } & \multicolumn{2}{|c|}{4 rooms } & \multicolumn{2}{|c|}{ Total } \\
\hline $0-9$ & 5 & $83.3 \%$ & 1 & $16.7 \%$ & 0 & $0.0 \%$ & 0 & $0.0 \%$ & 6 & $100.0 \%$ \\
\hline $10-19$ & 7 & $46.7 \%$ & 8 & $53.3 \%$ & 0 & $0.0 \%$ & 0 & $0.0 \%$ & 15 & $100.0 \%$ \\
\hline $20-29$ & 1 & $20.0 \%$ & 4 & $80.0 \%$ & 0 & $0.0 \%$ & 0 & $0.0 \%$ & 5 & $100.0 \%$ \\
\hline $30-39$ & 0 & $0.0 \%$ & 4 & $66.7 \%$ & 1 & $16.7 \%$ & 1 & $16.7 \%$ & 6 & $100.0 \%$ \\
\hline Total & 13 & $40.6 \%$ & 17 & $53.1 \%$ & 1 & $3.1 \%$ & 1 & $3.1 \%$ & 32 & $100.0 \%$ \\
\hline
\end{tabular}

Table 8 Floor areas and usages of Dalans

\begin{tabular}{|c|c|c|c|c|c|c|c|c|c|c|}
\hline $\begin{array}{l}\text { Dalan areas } \\
\left(\mathrm{m}^{2}\right)\end{array}$ & \multicolumn{2}{|c|}{$\mathrm{L} / \mathrm{L}+$} & \multicolumn{2}{|r|}{$\mathrm{S} / \mathrm{S}+$} & \multicolumn{2}{|r|}{$\mathrm{B} / \mathrm{B}+$} & \multicolumn{2}{|r|}{$\mathrm{H} / \mathrm{H}+$} & \multicolumn{2}{|c|}{ Total } \\
\hline $0-9$ & 2 & $8.7 \%$ & 2 & $40.0 \%$ & 2 & $66.7 \%$ & 0 & $0.0 \%$ & 6 & $18.8 \%$ \\
\hline 10-19 & 11 & $47.8 \%$ & 2 & $40.0 \%$ & 1 & $33.3 \%$ & 1 & $100.0 \%$ & 15 & $46.9 \%$ \\
\hline $20-29$ & 4 & $17.4 \%$ & 1 & $20.0 \%$ & 0 & $0.0 \%$ & 0 & $0.0 \%$ & 5 & $15.6 \%$ \\
\hline $30-39$ & 6 & $26.1 \%$ & 0 & $0.0 \%$ & 0 & $0.0 \%$ & 0 & $0.0 \%$ & 6 & $18.8 \%$ \\
\hline Total & 23 & $100.0 \%$ & 5 & $100.0 \%$ & 3 & $100.0 \%$ & 1 & $100.0 \%$ & 32 & $100.0 \%$ \\
\hline $\begin{array}{l}\text { L: Living room } \\
\text { S: Storage } \\
\text { B: Bathroom } \\
\text { H: Hall } \\
\text { Other: Storage }\end{array}$ & $/ \mathrm{Ba}$ & $\begin{array}{l}\text { L+: Livi } \\
\text { S+: Stor } \\
\text { B+: Bat } \\
\text { H+: Ha } \\
\text { hroom / I }\end{array}$ & 0 & $\begin{array}{l}\text { oom }+ \text { oth } \\
+ \text { other } \\
m+\text { other } \\
\text { ther }\end{array}$ & & & & $\begin{array}{l}\text { w to read: } \\
\text { means a l } \\
\text { ed as a livi } \\
\text { all area is }\end{array}$ & & $\begin{array}{l}\text { ample, } \\
\text { trea is } \\
\text { om and } \\
\text { for other. }\end{array}$ \\
\hline
\end{tabular}

Table 9 Dalan types and entrances of houses

\begin{tabular}{|c|c|c|c|c|c|c|}
\hline Dalan types & \multicolumn{2}{|c|}{$\begin{array}{c}\text { Underneath } \\
\text { Dalans }\end{array}$} & $\begin{array}{c}|c| \\
\text { Not } \\
\text { underneath } \\
\text { Dalans }\end{array}$ & \multicolumn{2}{|c|}{ Total } \\
\hline Traditional & 17 & $63.0 \%$ & 10 & $37.0 \%$ & 27 & $100.0 \%$ \\
\hline Modern & 4 & $80.0 \%$ & 1 & $20.0 \%$ & 5 & $100.0 \%$ \\
\hline Total & 21 & $65.6 \%$ & 11 & $34.4 \%$ & 32 & $100.0 \%$ \\
\hline
\end{tabular}

Table 10 Location of Dalans and entrances of houses

\begin{tabular}{|c|c|c|c|c|c|c|}
\hline Locations & \multicolumn{2}{|c|}{$\begin{array}{c}\text { Underneath } \\
\text { Dalans }\end{array}$} & $\begin{array}{c}\text { Not } \\
\text { underneath } \\
\text { Dalans }\end{array}$ & \multicolumn{2}{|c|}{ Total } \\
\hline Main street & 0 & $0.0 \%$ & 0 & $0.0 \%$ & 0 & $0.0 \%$ \\
\hline Sub-street & 7 & $58.3 \%$ & 5 & $41.7 \%$ & 12 & $100.0 \%$ \\
\hline Dead-end & 14 & $70.0 \%$ & 6 & $30.0 \%$ & 20 & $100.0 \%$ \\
\hline Total & 21 & $65.6 \%$ & 11 & $34.4 \%$ & 32 & $100.0 \%$ \\
\hline
\end{tabular}


buildings on the site. Therefore, whether the residents are constructing Dalans above the street due to lack of space is examined. In the study area, the outer walls of the building often form the boundary of the site, leaving no room between the building and the boundary. There is no open space found around the house, such as a garden or a backyard, with the exception of a courtyard. Therefore, the lot area is determined by the area of the house and the area of the courtyard. The courtyard is one of the features of traditional houses in the study area ${ }^{5}$ ) and important space for natural light, air circulation, and maintaining privacy ${ }^{12}$. Some houses on large sites have small structures in the courtyard (Fig. 5).

The possibility of expansion of space within the courtyard is examined in Table 11. The number of houses that can add a structure of the same area as their Dalans in the courtyard is slightly higher ( 18 or $56.2 \%$ ) compared to those without such possibilities (14 or $43.8 \%)$. However, this depends on the size of the site area. Among the houses with small site area (under $99 \mathrm{~m}^{2}$ ), two-thirds of houses (12 or 66.7\%) are unable to build a room within the courtyard. Therefore, for small houses, expansion of space may be a reason to build Dalans. Among houses with site areas over $100 \mathrm{~m}^{2}$, the majority of houses (12 or $85.7 \%$ ) are able to build a structure of the same area as Dalan in the courtyard. For larger houses, it is not necessary to build above the streets.

The correlation coefficient between the area of Dalans and the floor area of the houses (Fig. 6) shows a very low value of -0.07 . Thus, there is no relationship between the area of Dalans and the floor area of the houses. This indicates that Dalans are constructed regardless of the size of the site. In other words, the reason for the construction of Dalans cannot be explained only by space limitation. Therefore, there may be other reasons for building Dalans.

Another possible reason is security. For example, in the ancient fortified village of Castro in Greece, a network of bridges, ramparts, and alleyways was constructed to defend the town against invaders who might have penetrated the perimeter walls. ${ }^{13)}$ The structures built on the streets in Castro are similar to Dalans.

The positional relationship between the entrances and Dalans is
Table 11 Possibility of expansion of space within courtyards

\begin{tabular}{|c|c|c|c|c|c|c|}
\hline $\begin{array}{c}\text { Lot areas } \\
\left(\mathrm{m}^{2}\right)\end{array}$ & \multicolumn{2}{|c|}{ Possible } & \multicolumn{2}{|c|}{$\begin{array}{c}\text { Not } \\
\text { possible }\end{array}$} & \multicolumn{2}{c|}{ Total } \\
\hline $0-99$ & 6 & $33.3 \%$ & 12 & $66.7 \%$ & 18 & $100.0 \%$ \\
\hline $100-199$ & 8 & $80.0 \%$ & 2 & $20.0 \%$ & 10 & $100.0 \%$ \\
\hline $200-299$ & 3 & $100.0 \%$ & 0 & $0.0 \%$ & 3 & $100.0 \%$ \\
\hline $300-399$ & 0 & $0.0 \%$ & 0 & $0.0 \%$ & 0 & $0.0 \%$ \\
\hline $400-499$ & 0 & $0.0 \%$ & 0 & $0.0 \%$ & 0 & $0.0 \%$ \\
\hline $500-599$ & 1 & $100.0 \%$ & 0 & $0.0 \%$ & 1 & $100.0 \%$ \\
\hline Total & 18 & $56.2 \%$ & 14 & $43.8 \%$ & 32 & $100.0 \%$ \\
\hline
\end{tabular}

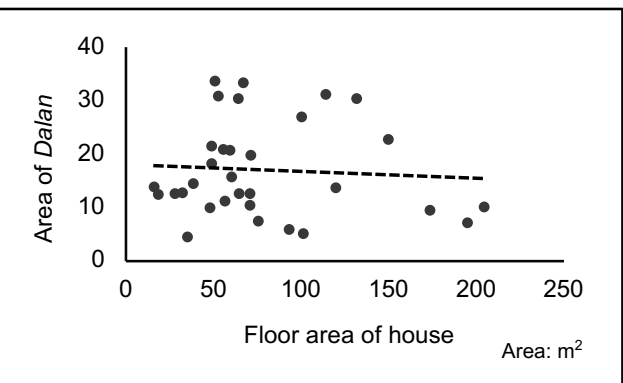

Fig. 6 Correlation of coefficient area of Dalans and floor area of houses

Table 12 Location of Dalans and entrances of houses by usage of Dalans

examined by usage in Table 12. It is found that when entrances are located underneath Dalans, the Dalans are mostly used as living rooms. When entrances are not underneath Dalans, Dalans are more often used as storage. If the Dalan is used as a living room, visitors can be seen from the upper floor. However, it may be possible that the usage has been changed over time. Therefore, the usage cannot directly explain the reason for building Dalans.

In addition, some Dalans have parapets with small openings facing streets in the study area (Fig. 7).vii) These could have been used as crenellation for defense purposes. But such details are found only in few and their function may be just openings for women to view the street while keeping their privacy as seen in other Islamic cities.

Perhaps Dalans have been built for multiple purposes. However, modern Dalans seem to have been built to add extra space for house sites. In addition, this analysis is based only on the existing Dalans. In this regard, more examination of historical literature is needed to understand the role of Dalans.

\section{Case Study: Mr. Haji Karim House}

Mr. Haji Karim (38 years old) is the owner of a traditional house with a traditional Dalan (Fig. 8). He has been living in this house since 2007 along with his nine family members. Therefore, the exact age of the house is unknown. The entrance of the house is located on a street with a dead-end. The house has two living floors with a ceiling height of 2.3 meters for each floor. Local construction materials have been used to build the house. The exterior walls of the house are built using stone masonry foundation, sun-dried bricks (Khesht-e Kham), and mud supported by wooden frames and covered by a mud-straw plaster. The interior walls are covered with fine mud plaster (Simgil) and then painted with several colors such as pink, white, and cream.

The first floor of Dalan, a walkway, is supported by wooden pillars on one side and stone masonry foundation and sun-dried brick walls 
of the house on the other. The second floor is constructed with sun-dried brick walls. Currently, the second floor of Dalan is used as storage (Pas Khana) and as a kitchen (Ashpaz Khana).

The small basement (height of 1.8 meters) under the living room is empty and unused due to rainwater from the courtyard. On the first floor, the entrance is covered by Dalan and leads to the courtyard (Haweli). The living room (Otaq Nisheman) on the first floor is on the north side, with three wooden windows (Se Dana Orsi) facing the courtyard. This room is currently unused due to deterioration. On the second floor, there is a guest room (Mihman Khana) and a living room (Otaq Nisheman).

On the rooftop, there is a small toilet (Badraft) at the corner (northeast). The rooftop (Takht Bam) is used for washing clothes during winters and sleeping during hot summers. There is an opening in the parapet wall of the rooftop of Dalan, which allows residents to observe the street from above.

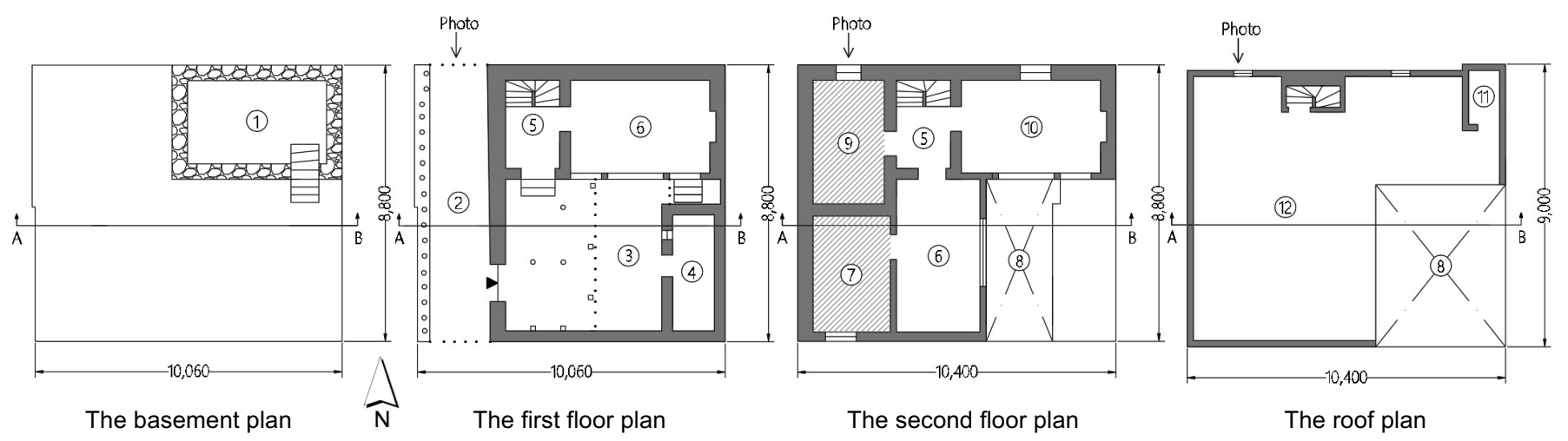

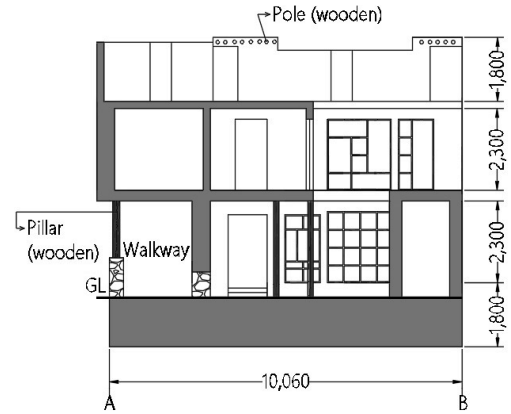

The section (A-B)

\begin{tabular}{|c|c|c|c|c|c|}
\hline \multicolumn{6}{|c|}{ Legend } \\
\hline No. & Dari & English & No. & Dari & English \\
\hline (1) & Tahkawi & Basement & (7) & Pas Khana & Storage \\
\hline (2) & Rah Raw & Walkway & (8) & - & Void \\
\hline (3) & Haweli & Courtyard & (9) & Ashpaz Khana & Kitchen \\
\hline (4) & Tashnab & Bathroom & (10) & $\begin{array}{c}\text { Mihman } \\
\text { Khana }\end{array}$ & Guest room \\
\hline (5) & Dahliz & Hall & (11) & Badraft & Toilet \\
\hline (6) & $\begin{array}{c}\text { Otaq } \\
\text { Nisheman }\end{array}$ & Living room & (12) & Takht Bam & Rooftop \\
\hline
\end{tabular}

Notes:

1) Indicated number for this house is (2) in Fig. 4.

2) All dimensions are in millimeters.

Fig. 8 Mr. Haji Karim house

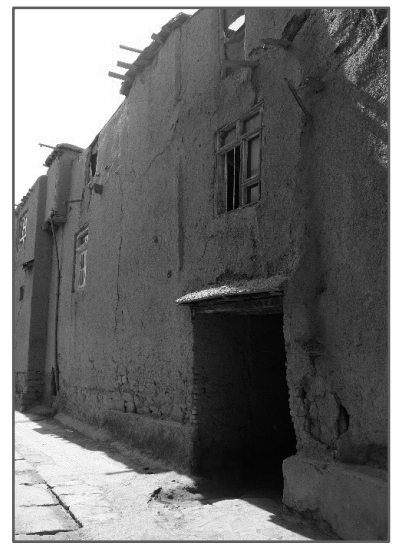

Photo of Dalan

\section{Destroyed Dalans}

The questionnaire survey of residents provided information on the 11 Dalans destroyed in the study area (Table 13). The distribution of destroyed Dalans is found on streets of all levels. In particular, three Dalans have been destroyed on main streets, where no Dalans are currently seen. Eight Dalans (72.7\%) were destroyed due to disasters; three (27.3\%) were destroyed due to house reconstruction.

The destruction of Dalans by disasters dated from the late 1990s to the 2010s.

\begin{tabular}{|c|c|c|c|c|c|c|c|c|c|c|c|}
\hline \multirow{2}{*}{\multicolumn{2}{|c|}{ Locations }} & \multicolumn{3}{|c|}{ Reconstructions } & \multicolumn{5}{|c|}{ Disasters } & \multirow{2}{*}{\multicolumn{2}{|c|}{ Total }} \\
\hline & & \multicolumn{2}{|r|}{$\begin{array}{l}\text { Built } \\
\text { modern } \\
\text { house }\end{array}$} & Improved & Earthquake & Rain/Flood & Fire & \multicolumn{2}{|r|}{ War } & & \\
\hline \multirow{2}{*}{ Main street } & No. & 1 & $50.0 \%$ & \begin{tabular}{l|l|}
1 & $100.0 \%$ \\
\end{tabular} & \begin{tabular}{l|l|}
1 & $33.3 \%$ \\
\end{tabular} & $0.0 \%$ & \begin{tabular}{l|l|}
0 & $0.0 \%$ \\
\end{tabular} & 0 & $0.0 \%$ & \multirow{2}{*}{3} & \multirow{2}{*}{$27.3 \%$} \\
\hline & Year & & 2014 & 2012 & 2009 & & & & & & \\
\hline \multirow{2}{*}{ Sub-street } & No. & 1 & $50.0 \%$ & \begin{tabular}{|l|l|}
0 & $0.0 \%$ \\
\end{tabular} & \begin{tabular}{l|l}
2 & $66.7 \%$ \\
\end{tabular} & $33.3 \%$ & \begin{tabular}{|l|l|}
1 & $100.0 \%$ \\
\end{tabular} & 0 & $0.0 \%$ & \multirow{2}{*}{5} & \multirow{2}{*}{$45.4 \%$} \\
\hline & Year & \multicolumn{2}{|c|}{2004} & $0.0 \%$ & 2002,2016 & 2004 & \begin{tabular}{|l|l|}
1998 \\
\end{tabular} & & & & \\
\hline \multirow{2}{*}{ Dead-end } & No. & 0 & $0.0 \%$ & $0.0 \%$ & \begin{tabular}{l|l}
0 & $0.0 \%$ \\
\end{tabular} & $66.7 \%$ & \begin{tabular}{|l|l|}
0 & $0.0 \%$ \\
\end{tabular} & 1 & $100.0 \%$ & \multirow{2}{*}{3} & \multirow{2}{*}{$27.3 \%$} \\
\hline & Year & & & & & 2008,2014 & & & 1994 & & \\
\hline \multirow{2}{*}{\multicolumn{2}{|c|}{ Total }} & 2 & $100.0 \%$ & \begin{tabular}{l|l}
1 & $100.0 \%$ \\
\end{tabular} & $100.0 \%$ & \begin{tabular}{|l|l|}
3 & $100.0 \%$ \\
\end{tabular} & \begin{tabular}{|l|l|}
1 & $100.0 \%$ \\
\end{tabular} & 1 & $100.0 \%$ & \multirow{2}{*}{\multicolumn{2}{|c|}{\begin{tabular}{l|l}
11 & $100.0^{\circ}$
\end{tabular}}} \\
\hline & & \multicolumn{3}{|c|}{$3(27.3 \%)$} & \multicolumn{5}{|c|}{$8(72.7 \%)$} & & \\
\hline
\end{tabular}


deteriorating and are in poor condition. The destruction of Dalans due to house reconstruction began in the early 2000s. Based on the findings, the destruction of Dalan due to reconstruction only happened along main streets and sub-streets, not on streets with dead-ends. This shows that the demand for redevelopment is stronger in locations with good access.

\section{Conclusion}

The purpose of this study has been to investigate the characteristics of Dalans in the Asheqan wa Arefan quarter. Presently, there are more Dalans on streets with dead-ends. There are no Dalan on main streets today, but some existed until recently. This is partly due to the demand for redevelopment in locations with good access. There are two types of Dalans found in the study area: traditional and modern. The degree of concentration (number of units per distance) of traditional Dalans is higher on streets with dead-ends. The degree of concentration of modern Dalans is higher on sub-streets. Among traditional Dalans, the majority have two-stories. In contrast, all of the modern Dalans have three-stories. The new three-story Dalans built with industrialized construction materials are changing the historical landscape with traditional two-story Dalans constructed with traditional materials. There are several possible reasons for building Dalans; climate, space limitation of the sites, and security being among them. In addition, one of the characteristics of Dalans in the Asheqan wa Arefan quarter is that there are cases where pillars are used as support due to structural reinforcement or lack of consensus between neighbouring residents. Further investigation of historical literature is necessary to understand the reasons for building Dalans.

Finally, whether or not Dalans should be conserved is a critical issue. Dalans are illegal structures on the public land under current municipality law and cannot formally be constructed today. It is also clear that in the event of a fire, Dalan interferes with fire fighting activity. In addition, the Dalans are not in good condition, and many are in need of repairs. A large number of Dalans have been removed in recent years because of a lack of durability. However, it is important to note that Dalans are part of the historical landscape from the past and are irreplaceable. The historical landscape with Dalans in the Asheqan wa Arefan quarter is unique within Kabul, as much of the historical landscape has been lost due to the long civil war. Under such circumstances, conservation of the remaining Dalans in the quarter is critical for the future of the cultural heritage of Afghanistan. An additional study, including deteriorating conditions of traditional houses and Dalans is needed to learn how to effectively conserve the area and raise awareness of their historical value among residents.

\section{References}

1) Breshna, Z: A Program for the Rehabilitation and Development of Kabul's Historic Center, Development of Kabul, pp.23-49, 2004

2) Noori, H. and Soave, A.: Urban Conservation in the Historic Neighborhoods of Kabul in Aga Khan Historic Cities Program, Urban Conservation and Area Development in Afghanistan, Aga Khan Trust for Culture, 2007

3) Najimi, A. W. and Leslie, J.: Urban Recovery: the Case of Historic Kabul, Heritage and Sustainability in the Islamic Built Environment, WIT Press, pp.2337,2012

4) Jodidio, P.: Afghanistan: Preserving Historic Heritage, PRESTEL, 2017

5) Azizi, M. U. and Ando, T.: A Study of Traditional Houses in West Asheqan Wa Arefan, Kabul City, Afghanistan, Journal of Architecture and Planning, (Transactions of AIJ) Vol. 85, No. 771, pp.1131-1139, 2020.5

6) Geist, J. F.: Arcades: The History of a Building Type, MIT Press, 1983

7) Hakim, B. S.: Arabic Islamic Cities Rev: Building and Planning Principles, Routledge, 2013

8) Ahang, M. A.: Yadasht haa wa Bardashthaye az Kabul Qadem, 2008 (in Dari language)

9) Kawish, K., Ando, T. and Samimi, S. A. B.: Historical Development of Bagh-e Dasht in Herat, Afghanistan: A Comprehensive Field Survey of Physical and Social Aspects, International Journal of Architectural and Environmental Engineering, WASET, pp.39-45, 2019

10) Nabizada, T. and Kita, M.: A Study on the Process and Mechanism of Transformation in Settlements in Kabul City, Journal of Architecture and Planning, (Transactions of AIJ) Vol. 77, No. 681, pp.2533-2543, 2012.11

11) Keshtkaran, P.: Harmonization between Climate and Architecture in Vernacular Heritage: A Case Study in Yazd, Iran, Procedia Engineering 21, pp.428438,2011

12) Ozkan, S.: Foreword - Courtyard: a Typology that Symbolises a Culture, in Courtyard Housing: Past, Present and Future, Taylor \& Francis, 2006

13) Goldfinger, M.: Villages in the Sun, Lund Humphries, 1969

\section{Notes}

i) In the first survey, Mr. Atta Mohammad, the 72-year-old representative of Gozar (community) helped us to collect data in the western part of the Asheqan wa Arefan. In the second survey, the Ministry of Interior- District 1's Kabul Police (Hawzi Awal Police Kabul) assisted the study in the eastern part.

ii) There are three types of houses found based on construction materials: 1) traditional, 2) modern, and 3) mixed. Traditional houses are built of local construction materials such as stone masonry, sun-dried bricks, wooden poles, and mud. Modern houses are built with industrialized construction materials such as fired bricks, steel, concrete, and cement. Mixed houses are a combination of traditional houses and modern houses (partially).

iii) There were two traditional houses with Dalans that were locked and no residents were living. One house owner of traditional house with Dalan refused the survey and allowed neither photographs nor the questionnaires.

iv) The term house stands for a built-up structure located inside of a lot excluding Dalan.

v) Room terms used in this paper have a different meaning. Living rooms are used for all-day activities, including living, eating, and sleeping. Halls are used as a circulation room to enter/exit yards, basements, living rooms, dining rooms, storages, kitchen, bathroom, and toilet.

vi) The term entrance is used for the main door located on the ground floor.

vii) Based on the observations, four traditional Dalans (No. 2, 18, 20, and 39 indicated in Fig. 4) have similar openings in their parapet wall facing streets. 


\section{Summary in Japanese}

本研究は、アフガニスタンのカブール旧市街地のアシュカン・ワ・アレファン地区を対象として、ダーラーン（住宅の一部である構造物が上 部を覆っている通路)を備えた住宅の特徴を明らかにすることを目的としている。まず、衛星写真を用いてべースマップを作成した上で、2018 年から 2019 年にかけて現地調查を行なった。ベースマップと現地調查により、ダーラーンの分布傾向、規模、平面形状、および利用状況などを 把握し、分析を行なった。さらに聞き取り調查により、ダーラーンを撤去した理由などを調査した。最後に、歴史的景観としてのダーラーンの 重要性を指摘し、その保全の必要性を述べている。

\section{Summary in English}

This paper aims to study the characteristics of houses with covered walkway structures locally called Dalan in the Asheqan wa Arefan quarter of Kabul Old City, Afghanistan. It examines their locations, distribution, access, the number of stories, plan types, space usages, and analysis of reasons for their construction and destruction. The house locations and their accessibility networks are indicated based on a satellite image followed by detailed field surveys conducted between 2018 and 2019 . Conclusions are drawn for the conservation of Dalans as part of cultural heritage in the historical landscape. 